\title{
Inhibition of Nitric Oxide Generation in Mononuclear Splenocytes from Multiple- Low-Dose-Streptozotocin Diabetic Mice
}

\author{
Liliana Karabatas and Claudia Pastorale
}

Centro de Investigaciones Endocrinológicas “Dr. César Bergadá” (CEDIE), Consejo Nacional de Investigaciones Científicas y Técnicas (CONICET) - División de Endocrinología, Hospital de Niños

"Ricardo Gutiérrez", Ciudad Autónoma de Buenos Aires, Argentina

Correspondence should be addressed to: Liliana Karabatas; Ikarabatas@cedie.org.ar

Received date: 1 October 2013; Accepted date: 3 December 2013; Published date: 31 December 2013

Academic Editor: Daniela Carlos

Copyright (C) 2013. Liliana Karabatas and Claudia Pastorale. Distributed under Creative Commons CCBY 3.0

\begin{abstract}
Mice injected with multiple low dose of streptozotocin (mld-SZ) or transferred with mononuclear splenocytes (MS) from mld-SZ donors constitute animal models that allow the study of autoimmune diabetes. Mld-SZ mice show a progressive beta-cell destruction iniciated during non-specific islet inflammation involving free radicals as nitric oxide $\left(\mathrm{NO}^{\circ}\right)$. Pharmacological inhibitors of $\mathrm{NO}^{\circ}$ synthase delay or prevent the outbreak of disease, but have deleterious side effects when administered in vivo. The aim of this study, was to clarify the role of $\mathrm{NO}^{\circ}$ on the ability of MS from mld-SZ mice to impair insulin secretion. Also, we investigated the beneficial effects of using $\mathrm{NO}^{\circ}$ synthase inhibitors in vitro on anti-beta cells agression. Methods: $\mathrm{NO}^{\circ}$ was measured in cultured MS and islets of Langerhans isolated from mice at days 4 to 16 after the first mld-SZ injection. MS were also cultured with an inhibitor of $\mathrm{NO}^{\circ}$

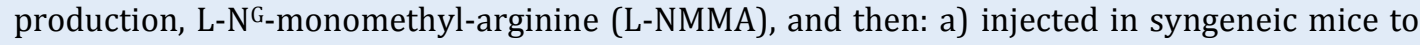
evaluate their insulin secretion patterns or b) co-cultured with islet cells to estimate the capacity of MS to exert in vitro cellular immune aggression. Results: Cultured islets of Langerhans and MS from mld-SZ mice showed increases in $\mathrm{NO}^{\circ}$ production ( $\left.\mathrm{p}>0.05\right)$. MS from mld-SZ mice, obtained at days 4 to 9 and precultured with L-NMMA showed ameliorations in their deleterious effect on insulin secretion from transferred recipient mice and from cocultured islet cells $(\mathrm{p}<0.05)$. Conclusions: These results suggest that the inhibition of $\mathrm{NO}^{\circ}$ production "in vitro" reduced the aggressive capacity of MS from mld-SZ mice avoiding, at least in part, beta cell damage and destruction.
\end{abstract}

Keywords: free radicals, murine autoimmune diabetes, non-specific islet inflammation, insulin secretion.

\section{Introduction}

Type 1 diabetes is a disease characterized by the specific destruction of insulin producing pancreatic beta-cells by the immune system (Cernea et al., 2008; Lehuen et al., 2010; Buschard, 2011; Eizirik et al., 2009; Padgett et al., 2013). Several animal models have been developed to 
study the islet physiopathology leading to autoimmune diabetes mellitus. One of these models is the multiple low dose of streptozotocin (mld-SZ) treated mouse that presents cellular and humoral immune reactions against beta cells, presumably, made antigenic by mld-SZ injections (Like et al., 1976; Per-Ola et al., 2000; Mabley et al., 2008) and shows a time course of histologic changes and progressive impairments in insulin secretion and lipid metabolism. The process includes an increment in apoptotic islet cells, followed by insulitis and microfocal islet cell death. Also, an increase of plasma free fatty acids is accompanied by a diminished activity of pyruvate dehydrogenase complex in skeletal muscle, suggesting a reduced glucose oxidation. These changes precede appearance of hyperglycemia and impaired insulin secretion (O'Brien et al., 1996; Pighin et al., 2005 and Karabatas et al., 2005).

Another animal model consists of an adoptive transfer of mononuclear splenocytes (MS) from mld-SZ diabetic donors (diab.MS) to healthy syngeneic recipients. In these mice, a diminished insulin secretion is present 15 days after the transfer procedure, and a preferential trapping of transferred diab.MS in islets of recipient mice was observed. Diab.MS obtained as early as day 4, were able to impair insulin secretion in transferred normal syngeneic recipients (Buschard et al., 1977; Pastorale et al., 2002; Karabatas et al., 2000 and 2005).

It has been reported that in mld-SZ treated mice, beta-cell destruction can be initiated during non-specific islet inflammation involving toxic mediators such as cytokines and highly reactive free radicals as oxygen species and nitric oxide $\left(\mathrm{NO}^{\circ}\right)$, produced by macrophages and endothelial cells. The beta-cells are particularly weakly protected against the toxicity of free radicals having a great vulnerability and sensitivity to this reactive species. Also the endocrine betacells become an important source of $\mathrm{NO}^{\circ}$ production when $\mathrm{NO}^{\circ}$ synthase is induced by IL-1 (Karabatas et al., 1996; Flodstrom et al., 1999; Rydgren et al., 2002; Mabley et al., 2004; Lenzen, 2008; Eizirik et al., 2009; Yasuda et al., 2009). By using pharmacological inhibitors of $\mathrm{NO}^{\circ}$ synthase, it has been evidenced that several of the deleterious actions of cytokines on rodent islet function "in vitro" are mediated by $\mathrm{NO}^{\circ}$ formation. Several reports have indicated that inhibition of free radicals production protect against mld-SZ-induced diabetes in mice, since in vivo studies have shown a delay or prevention of the outbreak of disease after treatment with $\mathrm{NO}^{\circ}$ synthase blockers (Karabatas et al., 1996; Maksimovic-Ivanic et al., 2002; Rydgren et al., 2002; Yang et al., 2003; Mabley et al., 2004 and 2008;). However, the lack of specificity of $\mathrm{NO}^{\circ}$ synthase pharmacological inhibitors, which to a varying degree block inducible and constitutive isoform of the enzyme, leads to uncontrolled side effects (blood pressure, neurotransmission, body weight) when administered in vivo.

The aim of this study was to investigate the role of $\mathrm{NO}^{\circ}$ on the ability of diab.MS to impair insulin secretion when injected in normal recipient mice or when co-cultured with dispersed islet cells. We studied nitric oxide production in cultured MS and islets of Langerhans, isolated from control or mld-SZ mice at 4, 6, 9, 12 and 16 days after the first injection. MS were also cultured with an inhibitor of nitric oxide production, $\mathrm{L}^{-} \mathrm{N}^{\mathrm{G}}$-monomethyl-arginine (L-NMMA). After being properly washed, these cells were used to study:

a) insulin secretion patterns in mice transferred with MS and

b) the capacity of diab.MS to exert an in vitro anti beta-cell immune aggression when co-cultured with dispersed islet cells.

\section{Materials and Methods}

\section{Animals}

Male C57BL/6J inbred mice weighing 21 to $25 \mathrm{~g}$ were obtained from the Centro Nacional de Genetica Medica, Buenos Aires, Argentina. Three-month-old male Wistar rats were also used as source of islet cells for co-culture experiments. Animals were housed in rooms with controlled temperature $\left(23^{\circ} \mathrm{C}\right)$ and a fixed 12-hour artificial light-dark cycle and had free access to water and to a standard laboratory chow (Carhill, Buenos Aires, Argentina). The protocols of animal use 
comply the guidelines recommended by the National Institutes of Health; and were approved by the Institutional Review Board at Hospital de Niños R. Gutiérrez (\#CODI-1811).

\section{Mice Injected with Multiple Low-Dose Streptozotocin (mld-SZ)}

C57BL/6J mice were injected intraperitoneally with $0.1 \mathrm{ml}$ citrate buffer ( $0.1 \mathrm{~mol} / \mathrm{l}$ trisodium citrate, $0.1 \mathrm{~mol} / \mathrm{l}$ citric acid, $\mathrm{pH}=4.5$ ), or with $40 \mathrm{mg} / \mathrm{kg}$ body weight of streptozotocin (SIGMA,USA) dissolved in $0.1 \mathrm{ml}$ citrate buffer, for five consecutive days. Animals were killed by cervical dislocation at days 4 (before the fourth injection), 6, 9, 12 or 16 after the first injection of SZ or buffer alone. Blood samples for determination of plasma glucose levels were obtained by retroorbital sinus puncture in unanesthetized, nonfasted mice $24 \mathrm{~h}$ before the beginning of mld-SZ or buffer injections and on day 4, 6, 9, 12 and 16 after the first injection. Pancreata and spleens were obtained from mice at the time of death.

Islets of Langerhans were obtained from collagenase-treated (SIGMA, USA) mice pancreas according to the method of Lacy and Kostianovsky (1967), and were perifused to evaluate glucose-induced insulin secretion, or cultured $22 \mathrm{~h}$ to evaluate $\mathrm{NO}^{\circ}$ production as described below.

Mononuclear splenocytes (MS) were aseptically isolated by shredding the spleens with steel wire mesh with sterile $\mathrm{NaCl} 154 \mathrm{mmol} / \mathrm{l}$ solution (Buschard et al., 1977; Karabatas et al., 2000 and 2005). MS were obtained using a Lymphoprep ${ }^{\mathrm{TM}}$ gradient (Nycomed Pharma, Norway) and then washed three times with sterile saline solution. Cell viability was assayed by the Trypan blue exclusion test (Phillips, 1973) and was 95 to $98 \%$. Isolated MS were used to evaluate $\mathrm{NO}^{\circ}$ production in $22 \mathrm{~h}$ cultures (see Nitrite production). MS were also cultured 22 hs without or with $0.5 \mathrm{mM} \mathrm{L-}$ $\mathrm{N}^{\mathrm{G}}$-monomethyl-arginine (L-NMMA, an inhibitor of nitric oxide synthase) and then transferred into syngeneic recipient mice or used to study "in vitro" cellular immune aggression (CIA).

\section{Nitrite Production in Cultured Islets and MS}

Islets of Langerhans and MS were obtained as described above from mice killed 4, 6, 9, 12 or 16 days after the first injection of mldSZ or citrate buffer alone. Groups of 200 islets were cultured for $22 \mathrm{~h}$ under an atmosphere of $95 \%$ air $/ 5 \% \mathrm{CO}_{2}$ in $400 \mu \mathrm{l}$ of RPMI 1640 (without phenol red) supplemented with $60 \mathrm{mg} / \mathrm{l}$ streptomycin, 1 $\mathrm{mmol} / \mathrm{l}$ sodium pyruvate, $10 \mathrm{ml} / \mathrm{l}$ nonessential amino acids 100X, $23.8 \mathrm{mmol} / \mathrm{l}$ $\mathrm{NaHCO}_{3}, 10 \mathrm{mmol} / \mathrm{l} \mathrm{HEPES}$ and $10 \%$ heat inactivated fetal calf serum (Gibco, UK). Also, $10^{7} \mathrm{MS}$ were cultured $22 \mathrm{~h}$ in culture medium.

Nitrite determination was performed with $250 \mu \mathrm{l}$ of supernatants of cultured islets or MS mixed with $250 \mu \mathrm{l}$ of Griess reagent and incubated for 10 minutes at room temperature. Nitrite was determined according to the method described by Green (1982). For our experiment, the detection limit was $0.5 \mu \mathrm{M}$, corresponding to 0.8 $\mathrm{pmol} /$ islet and $20 \mathrm{pmol} / 10^{6} \mathrm{MS}$. Intra- and interassay coefficients of variation on the standard curve were $1 \mu \mathrm{M}$ : 5.5\%, 9,4\%; 5 $\mu \mathrm{M}: 1.2 \%, 11.0 \% ; 25 \mu \mathrm{M}: 0.3 \%, 4.0 \%$. Results are expressed as pmol of nitrite per islet or pmol of nitrite per $10^{6} \mathrm{MS}$.

In another set of experiments, MS were cultured $22 \mathrm{~h}$ with or without L-NMMA 0.5 $\mathrm{mM}$ and nitrite was determined in supernatants. Nitrite levels of medium without MS (with or without L-NMMA) were subtracted if their values were above the detection limit.

Transfer of MS from Mld-SZ Mice to Syngeneic Animals

MS obtained from mld-SZ-mice (diab.MS) or from citrate buffer-injected mice (ctr.MS) at days $4,6,9,12$ or 16 after the first injection were washed twice with RPMI 1640 and cultured in this medium ( $5 \times 10^{7} \mathrm{MS} / 50 \mathrm{ml}$ of culture medium) for 22 hs with or without 0,5 mM L-NMMA. Afterward MS were washed twice with sterile saline solution. Viability of MS was then assesed by Trypan blue exclusion (Phillips, 1973) and $5 \times 10^{7}$ viable MS (90-95\% viability), suspended in $0.2 \mathrm{ml}$ sterile $\mathrm{NaCl} 154 \mathrm{mmol} / \mathrm{l}$ solution) were injected ip in $\mathrm{C} 57 \mathrm{BL} / 6 \mathrm{~J}$ male recipient 
mice of 22-24 g. Fifteen days after the transfer procedure, recipient mice were killed by cervical dislocation and their pancreas were quickly removed and processed for isolated islet perifusion as described below. Blood samples from unanesthetized, non-fasted recipient mice were obtained by retroorbital sinus puncture before and 15 days after being transferred. All experiments were carried out between 10:00 and 12:00 AM.

\section{Perifusion of Pancreatic Islets}

Islets of Langerhans from mld-SZ mice or from mice transferred with MS were perifused (25-40 islets per chamber) as described previously (Karabatas et al., 2000 and 2005). Krebs-Ringer-bicarbonate buffer was utilized as the perifusion buffer, and was supplemented with $1 \%(\mathrm{w} / \mathrm{v})$ dextran 70 (Sigma, St. Louis, Missouri, USA) and 3.3 $\mathrm{mmol} / \mathrm{l}$ glucose. The $\mathrm{pH}$ of the buffer, kept under constant $95 \% \mathrm{O}_{2}, 5 \% \mathrm{CO}_{2}$ gassing was 7.38-7.40. Samples were collected, after an initial $15 \mathrm{~min}$ recuperation period, on $0.2 \mathrm{ml}$ of $0.25 \mathrm{~mol} / \mathrm{l}$ EDTA in tubes kept at $4^{\circ} \mathrm{C}$ and immediately frozen at $-20^{\circ} \mathrm{C}$. Samples from $\min 1$ and 2 were used for baseline determinations. A stimulus of $16.5 \mathrm{mmol} / \mathrm{l}$ glucose was added to the perifusion buffer from min 3 to 40. Islets were perifused with buffer containing $3.3 \mathrm{mmol} / \mathrm{l}$ glucose from min 40 to 50 . Perifusion flux was $0.8-1.1$ $\mathrm{ml} / \mathrm{min}$.

\section{"In Vitro" Cellular Immune Aggression (CIA)}

The cellular immune aggression was evaluated measuring insulin secretion from dispersed rat islet cells co-cultured with MS. Diab.MS and ctr. MS were obtained at days 4, 6, 9, 12 and 16 after the first injection and were cultured 22 hs in RPMI 1640 with or without L-NMMA 0,5 $\mathrm{mM}$ and washed twice with sterile saline solution. Viable MS (90$95 \%$ viability) were used to determine CIA.

\section{Isolation of Dispersed Rat Islet Cells}

To obtain islet cells suspensions, freshly isolated rat islets (from collagenase treatment) were subjected to EDTA and trypsin (Sigma, St. Louis, Mo., USA) (Ono, 1977). The cells were suspended in basal Minimal Essential Medium with Eagle salts supplemented with $10 \%(\mathrm{v} / \mathrm{v})$ fetal calf serum, $2 \mathrm{mmol} / \mathrm{l}$ glutamine, $1 \mathrm{mmol} / \mathrm{l}$ sodium piruvate, $0.814 \mathrm{mg} / \mathrm{l}$ non-essential amino acids (Gibco, UK), $100 \mathrm{U} / \mathrm{ml}$ penicillin and $100 \mu \mathrm{g} / \mathrm{ml}$ streptomycin. Cell viability was estimated by the Trypan blue exclusion test (Phillips, 1973) and only cell suspensions having at least $90 \%$ viable cells were employed.

\section{Islet Cell Stimulation}

The islet cell suspension was placed in 96well Falcon microtest plates (Becton Dickinson, USA) at $5 \times 10^{3}$ cells $/ 100 \mu \mathrm{l}$ per well, with addition of $4 \times 10^{5} \mathrm{MS}$ from either control or diabetic mice (in $100 \mu \mathrm{l}$ ), or basal medium $(100 \mu \mathrm{l})$ and incubated for $18 \mathrm{~h}$. Ten wells were used for each determination. At the end of this period, wells were carefully washed and the supernatant collected to asses prestimulatory insulin release. The medium was replaced by $200 \mu \mathrm{l}$ basal medium (glucose $5.5 \mathrm{mmol} / \mathrm{l}$ ) or $200 \mu \mathrm{l}$ stimulatory medium (glucose $16.5 \mathrm{mmol} / \mathrm{l}$ plus theophylline $5.5 \mathrm{mmol} / \mathrm{l}$ ). Five wells were used for each basal or stimulatory medium. MS remained with cells during both basal and stimulatory periods. Supernatants were withdrawn after $5 \mathrm{~min}$ and rapidly frozen for insulin determinations. Islet cells function was expressed as the insulin secretion $(\mu \mathrm{U} / 5000$ cells) during 5-min incubation period in the presence of basal or stimulatory medium (Boitard et al., 1982; Karabatas et al., 1996 and 2000). Results of cellular immune aggression test were reproducible with a $3.89 \%$ inter-assay and $4.20 \%$ intra-assay coefficient of variation (CV), both for ctr.MS or diab.MS.

\section{Analytical Methods}

Serum glucose levels from non fasted mice were determined using Glicemia Enzimatica Kit (Wiener Lab, Buenos Aires, Argentina). Insulin was determined in samples from perifusion and in supernatants from islet cells-MS cultures by the method of Herbert et al. [33]. Pork monoiodine ${ }^{125}$ I-insulin was obtained from CENEXA, Facultad de Medicina, Universidad Nacional de La Plata, Argentina. Rat standard insulin was obtained from Novo Research Laboratories (Denmark). Guinea pig anti-porcine insulin antiserum was sufficiently "non-specific" as 
to allow pork labeled insulin to be displaced by mouse and rat insulin. Insulin assay sensitivity was $0.5 \mu \mathrm{U} / \mathrm{ml}$; intra-assay $\mathrm{CV}$ was $8.7 \%, 6.2 \%$ and $5.1 \%$ for $1-5,5-10$ and 10-50 $\mu \mathrm{U}$ insulin/ml determination ranges respectively; inter-assay CV were 6.6\%, 5.0\% and $5.2 \%$ for the given ranges.

\section{Statistical Analysis}

Results were expressed as mean \pm SEM. Statistical significance was determined by ANOVA for plasma glucose levels, insulin secretion and nitrite concentration. When significance was found, Scheffe's post hoc comparisons were made; p less than 0.05 was accepted as statistically significant. To evaluate insulin secretion from perifused pancreatic islets we integrated the areas under stimulated-insulin secretion curves: first secretory peak was integrated between $\min 3$ to 7; and the second peak between min 9 to 40 of perifusion.

The experimental design and different procedures were schematized in Figure 1

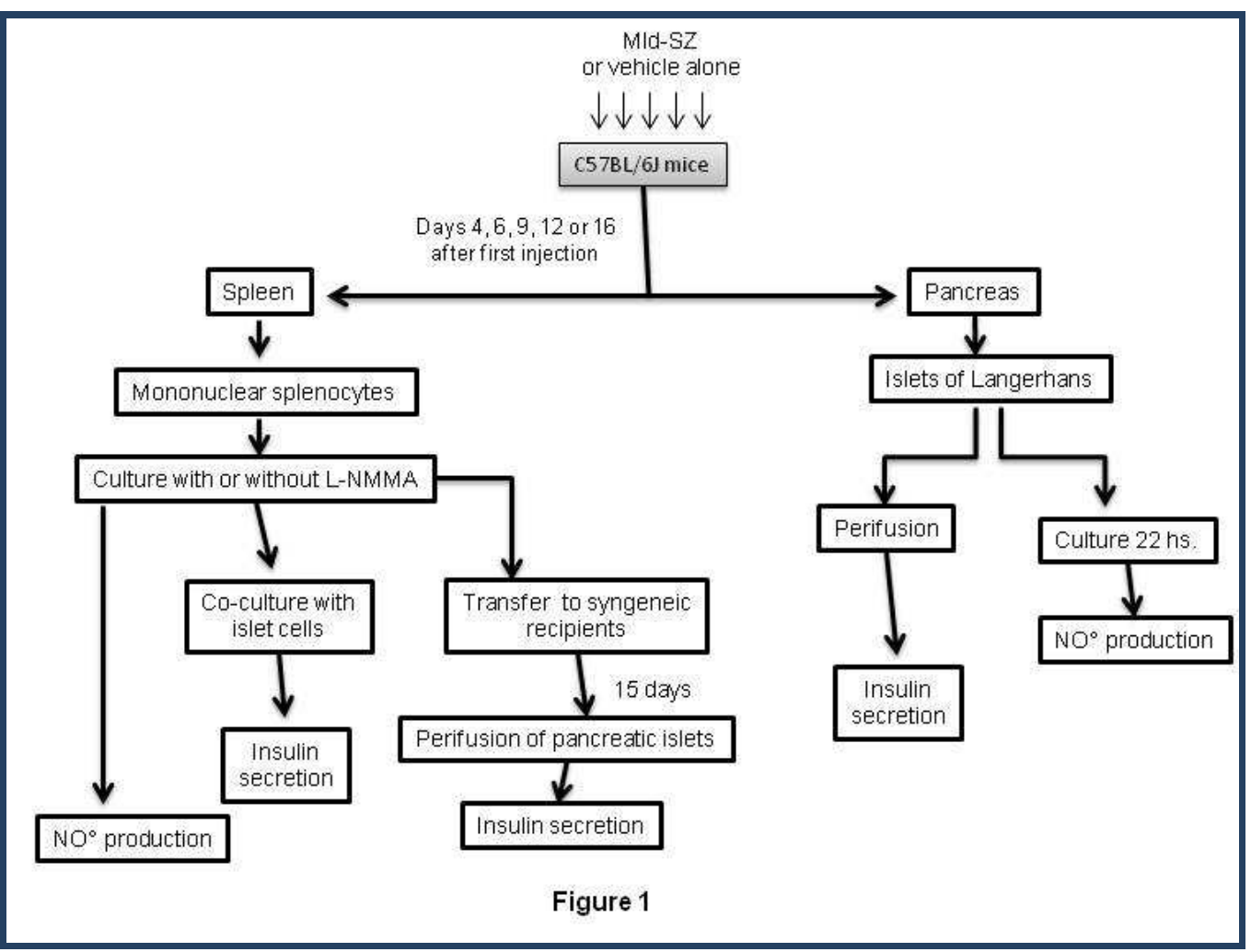

Figure 1: Schematic representation of the experimental design. Briefly, pancreas or spleens from mld-SZ or control mice were obtained at 4, 6, 9, 12 and 16 days after the first injection. Isolated pancreatic islets were perifused to evaluate glucose-stimulated insulin secretion. MS were cultured with or without L-NMMA, washed and transferred to syngeneic mice or co-cultured with islet cells. Insulin secretion was evaluated in recipient mice by islet perifusions or in co-culture supernatants.

Also, $\mathrm{NO}^{\circ}$ production was measured in islets and MS after 22 hour culture.

\section{Results}

Mice injected with mld-SZ show a significant and progressive increase in serum glucose levels from day 9 to day 16 after the first injection of the diabetogenic drug (Table 1). 
Table 1: Non-Fasted Serum Glucose (Mg/DI) from Control or Mld-SZ Treated Mice.

\begin{tabular}{|c|c|c|c|c|c|}
\hline $\begin{array}{c}\text { Days after } \\
\text { 1st Injection }\end{array}$ & 4 days & 6 days & 9 days & 12 days & 16 days \\
\hline Control Mice & $\begin{array}{c}169 \pm 4 \\
\mathrm{n}=23\end{array}$ & $\begin{array}{c}174 \pm 4 \\
\mathrm{n}=21\end{array}$ & $\begin{array}{c}169 \pm 5 \\
\mathrm{n}=19\end{array}$ & $\begin{array}{c}163 \pm 4 \\
\mathrm{n}=20\end{array}$ & $\begin{array}{c}170 \pm 3 \\
\mathrm{n}=21\end{array}$ \\
\hline Mld-SZ Mice & $\begin{array}{c}172 \pm 3 \\
\mathrm{n}=26\end{array}$ & $\begin{array}{c}167 \pm 2 \\
\mathrm{n}=23\end{array}$ & $\begin{array}{c}338 \pm 14^{\mathrm{ab}} \\
\mathrm{n}=26\end{array}$ & $\begin{array}{c}367 \pm 19^{\mathrm{ab}} \\
\mathrm{n}=20\end{array}$ & $\begin{array}{c}440 \pm 25^{\mathrm{abc}} \\
\mathrm{n}=22\end{array}$ \\
\hline
\end{tabular}

a: $\mathrm{p}<0.01$ vs control mice;

b: $p<0.01$ vs mld-SZ mice from days 4 and 6 ;

c: $\mathrm{p}<0.05$ vs mld-SZ mice at days 9 and 12 .

Basal insulin secretion levels from perifused pancreatic islets are not significantly different between control and mld-SZ mice at all intervals (controls: 0.23 $\pm 0.02,16$ days after mld-SZ: $0.24 \pm 0.01$ $\mu \mathrm{U} / \mathrm{min} /$ islet; $\mathrm{n}=4, \mathrm{p}$ : N.S.).

Figure 2 shows the waveforms of glucosestimulated insulin secretion from perifused islets (upper panel) and the areas under first and second phases of glucose-induced insulin secretion (lower panel). Control mice present a biphasic pattern with a first phase lasting from minute 3 to minute 7 , and the second phase lasting from minute 10 to 40. Afterwards, when perifusion buffer contains $3.3 \mathrm{mM}$ glucose, insulin secretion returns to basal levels (min 50). Mld-SZ mice present normal secretory patterns at days 4 and 6 and significant reductions in the first phase of glucosestimulated insulin secretion at days 9, 12 and 16 compared with control mice. Values obtained at days 12 and 16 are lower than those from day 9. The second phase of glucose-stimulated insulin secretion is significantly decreased in mld-SZ mice at $\begin{array}{llll}\text { days } & 12 & \text { and }\end{array}$ 


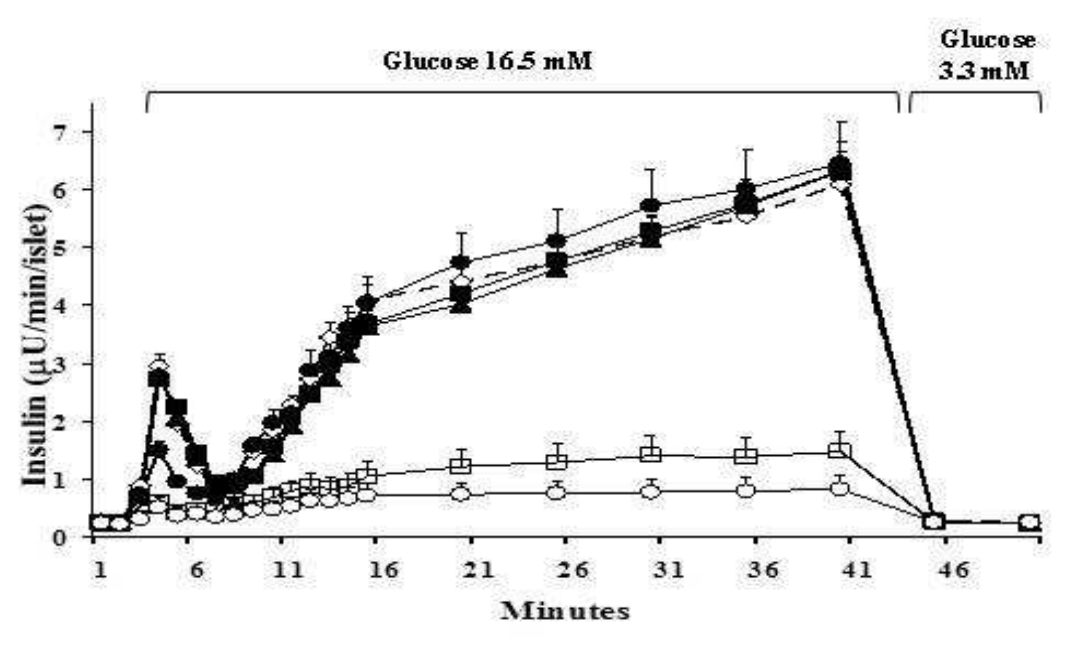

\begin{tabular}{|c|c|c|c|c|}
\hline $\begin{array}{c}\text { Days after first } \\
\text { injection }\end{array}$ & $\begin{array}{c}\text { First phase of insulin secretion } \\
(\mu \mathrm{U} / 5 \mathrm{~min} / \mathrm{islet})\end{array}$ & \multicolumn{2}{|c|}{$\begin{array}{c}\text { Second phase of insulin } \\
\text { secretion } \\
(\mu \mathrm{U} / 32 \mathrm{~min} / \text { islet })\end{array}$} \\
\hline & Control mice & MId-SZ mice & Control mice & Mld-SZ mice \\
\hline & $7.93 \pm 0.31$ & $8.21 \pm 0.38$ & $149.75 \pm 9.12$ & $143.70 \pm 5.35$ \\
\hline 4days & $8.44 \pm 0.24$ & $7.78 \pm 0.41$ & $148.92 \pm 4.92$ & $140.32 \pm 4.22$ \\
\hline 6 days & $7.67 \pm 0.42$ & $4.64 \pm 0.19 \mathrm{ab}$ & $149.18 \pm 4.26$ & $154.83 \pm 9.87$ \\
\hline days & $7.78 \pm 0.40$ & $2.49 \pm 0.09 \mathrm{abc}$ & $145.50 \pm 2.98$ & $38.64 \pm 1.72 \mathrm{abc}$ \\
\hline 12 days & $7.87 \pm 0.20$ & $1.79 \pm 0.08 \mathrm{abc}$ & $147.47 \pm 4.28$ & $24.27 \pm 1.10 \mathrm{abc}$ \\
\hline 16 days & \multicolumn{3}{|c|}{}
\end{tabular}

Figure 2

Figure 2: Upper panel: Glucose-stimulated insulin secretion patterns in perifused islets of Langerhans from C57BL/6J mice injected with mld-SZ or citrate buffer. Isolated islets were obtained at days $4-\square-, 6-\Delta-, 9-0-, 12-\square-$ and $16-0-$ after the first injection of mld-SZ, or at 12 days after citrate injection --- $\diamond---$. Lower panel: Areas under first or second phases of glucose induced insulin secretion from control or mld-SZ injected mice.a- $p<0.01$ versus control mice; $b$ - $p<0.01$ versus mld-SZ mice at days 4 and 6; $c$ - $p<0.01$ vs mld-SZ mice at day 9. At least 5 perifusions were analyzed for each group. Pancreata from 2 mice were pooled when islets were obtained at days 9, 12 or 16 from mld-SZ mice. Each pool was consider as $n=1$. Each pancreas of a single mouse was digested when islets were isolated from control or mld-SZ mice at days 4 or 6 .

Cultured islets of Langerhans, isolated from mld-SZ mice, show a significant increase in nitric oxide production, at all time intervals, when compared with control mice. The highest value is obtained when islets are isolated at day 6 after the first injection of the diabetogenic drug (Figure 3 , upper panel). In agreement with these findings, cultured diab.MS also show increments in nitric oxide production, reaching the maximum level at day 6 (Figure 3, lower panel). In another set of 
experiments ctr.MS and diab.MS were isolated at 6 or 16 days after the first injection and cultured 22 hours with or without $0.5 \mathrm{mM}$ L-NMMA to evaluate nitric oxide production in supernatants. Results show that L-NMMA decreases the production of nitric oxide in diab.MS to control values while it has no effect on ctr. MS (Figure 4).

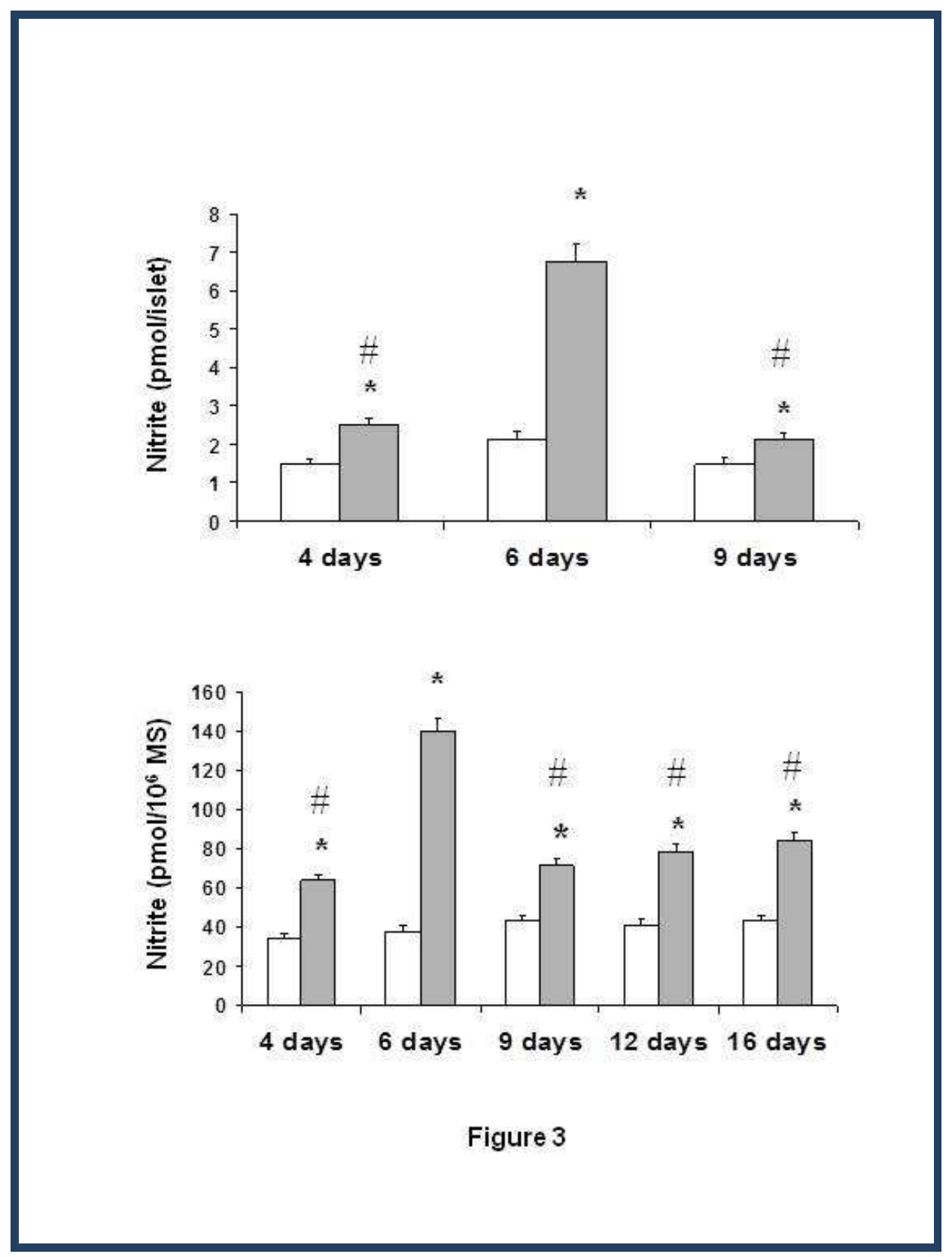

Figure 3: Nitrite in supernatants from islet (upper panel) or mononuclear splenocytes (MS) (lower panel) cultures. Islets of Langerhans and MS were isolated from citrate injected (white bars) or mld-SZ mice (dotted bars) at 4, 6, 9, 12 and 16 days after the first injection, as indicated. Experiments with MS were performed in duplicate. ${ }^{*} \mathbf{p}<0.01$ vs. controls; \# $p<0.01$ vs mld-SZ from day $6 ; n=5$ to 9 in each group. 


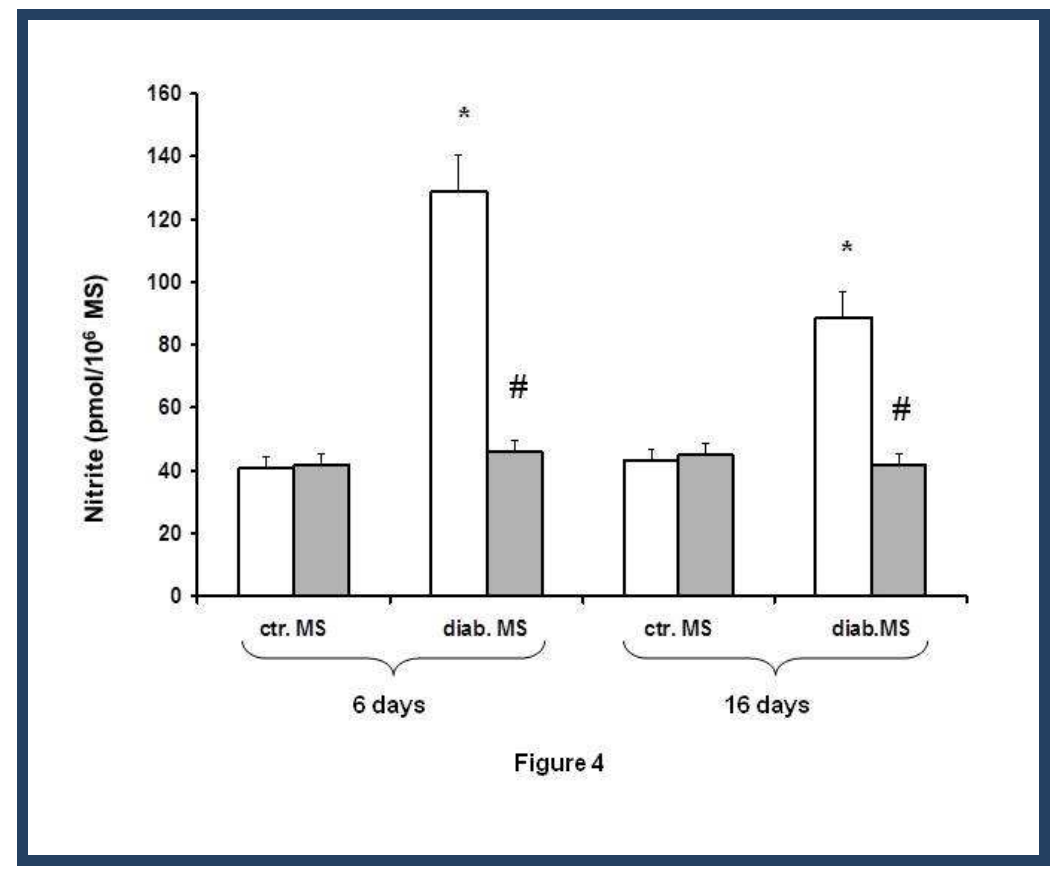

Figure 4: Nitrite in supernatants from MS cultures. MS were isolated from citrate injected (ctr. MS) or mld-SZ mice (diab.MS) at days 6 and 16 after the first injection and precultured with (dotted bars) or without (white bars) LNMMA $0.5 \mathrm{mM}$. ${ }^{*} \mathrm{p}<0.01$ vs ctr. MS without LNMMA; \#p<0.01 vs. diab.MS without LNMMA; $n=4$ or 5 . Each experiment was performed in duplicate.

Diab.MS impair beta cell function when transferred to normal syngeneic mice, since perifused freshly isolated islets from recipient animals show a significant reduction in first-phase of glucosestimulated insulin secretion. However, when diab.MS were precultured with LNMMA before being transferred, we observe changes in this deleterious effect since first phases of insulin secretion are:

a) normal in mice transferred with L-
NMMA-treated diab.MS obtained at days 4 and b) partially impaired when these MS are isolated at days 6 and 9.

On the other hand, preculture with LNMMA has no effect when diab.MS were obtained at days 12 or 16, since insulin secretion show similar reductions (comparing to recipients of diab.MS without L-NMMA). (Table 2).

Table 2: First phase of glucose-induced insulin secretion ( $\mu \mathrm{U} .5 \mathrm{~min}^{-1}$. Islet $\left.{ }^{-1}\right)$ in perifused pancreatic islets from mice transferred with mononuclear spleen cells (MS). MS were obtained from syngeneic donors at day 4, 6, 9, 12 and 16 after injections with mld-SZ or buffer.

\begin{tabular}{|c|c|c|c|c|}
\hline & \multicolumn{2}{|c|}{ Mice Transferred with Ctr.MS } & \multicolumn{2}{c|}{ Mice Transferred with Diab.MS } \\
\cline { 2 - 5 } & $\begin{array}{c}\text { MS Precultured } \\
\text { without LNMMA }\end{array}$ & $\begin{array}{c}\text { MS Precultured } \\
\text { with LNMMA }\end{array}$ & $\begin{array}{c}\text { MS Precultured } \\
\text { without LNMMA }\end{array}$ & $\begin{array}{c}\text { MS Precultured } \\
\text { with LNMMA }\end{array}$ \\
\hline 4 days & $7.50 \pm 0.55$ & $8.52 \pm 0.36$ & $4.99 \pm 0.11^{\mathrm{b}}$ & $7.52 \pm 0.30^{\mathrm{ac}}$ \\
& $\mathrm{n}=4$ & $\mathrm{n}=4$ & $\mathrm{n}=8$ & $\mathrm{n}=8$ \\
\hline 6 days & $7.97 \pm 0.16$ & $\begin{array}{c}8.06 \pm 0.21 \\
\mathrm{n}=4\end{array}$ & $\begin{array}{c}4.97 \pm 0.10^{\mathrm{b}} \\
\mathrm{n}=7\end{array}$ & $\begin{array}{c}6.66 \pm 0.28^{\mathrm{abc}} \\
\mathrm{n}=7\end{array}$ \\
\hline 9 days & $\mathrm{n}=4$ & $8.20 \pm 0.40$ & $5.02 \pm 0.16^{\mathrm{b}}$ & $6.99 \pm 0.30^{\mathrm{abc}}$ \\
& $8.32 \pm 0.31$ & $\mathrm{n}=4$ & $\mathrm{n}=4$ & $\mathrm{n}=6$ \\
\hline
\end{tabular}




\begin{tabular}{|c|c|c|c|c|}
\hline \multirow{2}{*}{} & \multicolumn{2}{|c|}{ Mice Transferred with Ctr.MS } & \multicolumn{2}{c|}{ Mice Transferred with Diab.MS } \\
\cline { 2 - 5 } & $\begin{array}{c}\text { MS Precultured } \\
\text { without LNMMA }\end{array}$ & $\begin{array}{c}\text { MS Precultured } \\
\text { with LNMMA }\end{array}$ & $\begin{array}{c}\text { MS Precultured } \\
\text { without LNMMA }\end{array}$ & $\begin{array}{c}\text { MS Precultured } \\
\text { with LNMMA }\end{array}$ \\
\hline 12 days & $8.23 \pm 0.37$ & $7.56 \pm 0.24$ & $4.74 \pm 0.24^{\mathrm{b}}$ & $5.12 \pm 0.25^{\mathrm{b}}$ \\
& $\mathrm{n}=4$ & $\mathrm{n}=4$ & $\mathrm{n}=4$ & $\mathrm{n}=5$ \\
\hline 16 days & $7.92 \pm 0.17$ & $\begin{array}{c}8.00 \pm 0.25 \\
\mathrm{n}=4\end{array}$ & $\begin{array}{c}5.00 \pm 0.11^{\mathrm{b}} \\
\mathrm{n}=4\end{array}$ & $\begin{array}{c}5.72 \pm 0.43^{\mathrm{b}} \\
\mathrm{n}=6\end{array}$ \\
\hline
\end{tabular}

a: $\mathrm{p}<0.01$ vs recipients of diab.MS without LNMMA;

b: $p<0.01$ vs recipients of ctr.MS precultured on the same conditions;

c: $p<0.01$ vs recipients of diab.MS obtained at days 12 and 16 and pre-cultured with LNMMA.

Each perifusion corresponded to islets isolated from a a single transferred mouse.

In order to investigate the in vitro cellular immune aggression we co-cultured dispersed rat islet cells with ctr.MS or diab.MS, and measured insulin secretion in the culture medium. No significant differences were found in the prestimulatory period or in basal condition (data not shown). Under stimulatory condition, insulin is significantly reduced when islet cells are co-cultured with diab.MS (obtained at all time intervals). However when diab.MS, obtained at days 4 to 12 , were precultured with L-NMMA, they exert a lower functional immune aggression against islet cells, since insulin levels in the culture medium are significantly higher. At later stages (day 16) L-NMMA had no preventive effect on diab.MS since they are capable to impair insulin secretion to similar levels than diab.MS without LNMMA (Table 3).

Table 3: Cellular immune aggression evaluated as stimulated-insulin secretion ( $\mu U$ U. 5 min $^{-1} .5000$ cells $^{-1}$ ) in dispersed islet cells co-cultured with mononuclear spleen cells (MS). MS were obtained at day 4, 6, 9, 12 and 16 from mice injected with mld-SZ or buffer.

\begin{tabular}{|c|c|c|c|c|}
\hline & \multicolumn{2}{|c|}{ Islet Cells Co-Cultured with Ctr.MS. } & \multicolumn{2}{c|}{ Islet Cells Co-Cultured with Diab.MS. } \\
\hline \multirow{2}{*}{ Days } & $\begin{array}{c}\text { MS Precultured } \\
\text { without LNMMA }\end{array}$ & $\begin{array}{c}\text { MS Precultured } \\
\text { with LNMMA }\end{array}$ & $\begin{array}{c}\text { MS Precultured } \\
\text { without LNMMA }\end{array}$ & $\begin{array}{c}\text { MS Precultured } \\
\text { with LNMMA }\end{array}$ \\
\hline 4 days & $\begin{array}{c}29.06 \pm 0.26 \\
\mathrm{n}=4\end{array}$ & $\begin{array}{c}29.09 \pm 0.66 \\
\mathrm{n}=4\end{array}$ & $\begin{array}{c}17.70 \pm 1.25^{\mathrm{b}} \\
\mathrm{n}=5\end{array}$ & $\begin{array}{c}26.32 \pm 0.73^{\mathrm{abc}} \\
\mathrm{n}=5\end{array}$ \\
\hline 6 days & $29.00 \pm 0.41$ & $29.19 \pm 0.31$ & $19.52 \pm 0.93^{\mathrm{b}}$ & $25.15 \pm 0.69^{\mathrm{abc}}$ \\
& $\mathrm{n}=4$ & $\mathrm{n}=4$ & $\mathrm{n}=5$ & 5 \\
\hline 9 days & $29.78 \pm 0.57$ & $\begin{array}{c}30.26 \pm 0.29 \\
\mathrm{n}=5\end{array}$ & $\begin{array}{c}15.33 \pm 0.88^{\mathrm{b}} \\
\mathrm{n}=5\end{array}$ & $\begin{array}{c}21.52 \pm 0.40^{\mathrm{ab}} \\
\mathrm{n}=5\end{array}$ \\
\hline 12 days & $29.25 \pm 0.39$ & $28.76 \pm 0.27$ & $17.64 \pm 0.47 \mathrm{~b}$ & $22.74 \pm 0.63^{\mathrm{bb}}$ \\
& $\mathrm{n}=4$ & $\mathrm{n}=4$ & $\mathrm{n}=4$ & $\mathrm{n}=4$ \\
\hline 16 days & $29.11 \pm 0.70$ & $28.94 \pm 0.16$ & $14.02 \pm 0.43^{\mathrm{b}}$ & $14.64 \pm 0.58^{\mathrm{bd}}$ \\
& $\mathrm{n}=4$ & $\mathrm{n}=4$ & $\mathrm{n}=5$ & $\mathrm{n}=5$ \\
\hline
\end{tabular}

a: $\mathrm{p}<0.01$ vs islet cells plus diab.MS without LNMMA;

$\mathrm{b}: \mathrm{p}<0.05$ vs islet cells plus ctr.MS precultured on the same conditions;

c: $p<0.01$ vs islet cells plus diab.MS obtained at days 9,12 and 16 and precultured with LNMMA;

$\mathrm{d}: \mathrm{p}<0.01$ vs islet cells plus diab.MS obtained at days 9 and 12 and precultured with LNMMA.

Five wells were used for each determination.

\section{Discussion}

A variety of cellular components are involved in the development of type 1 diabetes: both CD4+ and CD8+ T cells, monocytes, macrophages and NK cells. Also, proinflammatory cytokines play essential roles in the pathogenesis of the 
disease (Lehuen et al., 2010; Padgett et al., 2013) .

Mice injected with mld-SZ develop autoimmune diabetes with the appearance of progressive hyperglycemia. Mld-SZ affects beta cells eliciting a non-specific islet inflammation involving toxic mediators as free radicals and cytokines followed by immune destruction and insulitis. In this model, a variety of procedures demonstrated the role of immune cells in beta cell damage. Herold et al., (1987) showed that administration of anti-L3T4 or anti-Lyt-2 monoclonal antibodies to mld-SZ mice promoted a reduction in hyperglycemia and in splenic T-lymphocytes subsets, and a prevention of insulitis. Also, athymic mice did not develop insulitis or hyperglycemia after adminitration of mld-SZ, but when immunity was restored by thymus grafting insulitis and hyperglycemia became evident. This highlight the role of T cells in the development of the disease (Paik et al., 1980; Nakamura et al., 1984). In addition, it has been proposed that the balance between subsets of $\mathrm{T}$ cells (pro or anti inflammatory) is important to prevent type 1 diabetes. Yaochite et al., (2013) demonstrated that mice lacking IL-17 receptor showed an impairment in mld-SZ diabetic course with reduced insulitis and beta cell preservation.

Earlier events that preceded the onset of hyperglycemia had been described in mldSZ mice: a decrease of GLUT2 protein and mRNA expression in pancreatic islets, increases in the percentage of islet apoptotic cells and incipient insulitis at day 6 after the first streptozotocin injection. The free radical nitric oxide $\left(\mathrm{NO}^{\circ}\right)$, generated by inducible nitric oxide synthase (iNOS) has been implicated in beta cell destruction leading to type 1

diabetes since iNOS is mostly not expressed under normal conditions but can be induced by cytokines to produce large amounts of $\mathrm{NO}^{\circ}$, that often function as a cytotoxic molecule for beta cells ( $\mathrm{O}^{\prime}$ Brien et al., 1996; Wang et al., 1998; Rydgren et al., 2002; Karabatas et al., 2005; Mabley et al., 2004 and 2008; Lenzen, 2008; Cernea et al., 2008; Eizirik et al., 2009; Yasuda et al., 2009; Lehuen et al., 2010). In agreement with these previous findings (2005), we show here that hyperglycemia is present in mld-SZ-treated mice from day 9 after the first injection. Moreover, perifused pancreatic islets show a progressive reduction in the first phase of glucoseinduced insulin secretion while the second secretory peak significantly diminishes from day 12 .

We have also found that increments in $\mathrm{NO}^{\circ}$ production, both in cultured islets and MS from mld-SZ, appear as early as day 4 after the first injection of the diabetogenic drug, reaching its highest level at day 6. This increased iNOS activity may constitute an important factor in the cascade of events leading to beta cells dysfunction and culminating in mld-SZ-induced diabetes. Flodstrom et al., (1999) and Per-Ola et al., (2000) reported that iNOS knockout mice treated with mld-SZ show: no changes in islet blood flow, a markely decrease in insulitis and a reduced sensitivity to develop overt diabetes. These findings have raised interest in the question of whether inhibitors of iNOS could be used to prevent the development of Type 1 diabetes.

A variety of procedures and therapies that delete, suppress, or modulate functions of the immune and inflammatory system can block the response against islet beta cells (Stosic-Grijicic et al., 2001; Rydgren et al., 2002; Yang et al., 2003; Mabley et al., 2004 and 2008 and Karatug et al., 2013). In a previous work we showed that mld-SZ mice injected ip with L-NMMA had normoglycemia, preserved first and second glucose-induced insulin secretion and a diminished anti-beta cell immune aggression (Karabatas et al., 1996). It has been reported that the use of an iNOS inhibitor plus an oxygen species scavenger leads to decreases in hyperglycemia and incidence of diabetes, a higher pancreatic insulin content and absence of pancreatic oxidative stress (Mabley et al., 2004). Also, mld-SZ mice treated with micophenolato mofetil reduced local production of IFNgamma as well as IL-12 and $\mathrm{NO}^{\circ}$ production by spleen and peritoneal cells in mld-SZ mice (Maksimovic-Ivanic et al., 2002). Moreover, Stocic-Grijicic et al., (2001) and Mabley et al., (2008) showed, in 
"in vivo" studies, a delay or prevention of the outbreak of disease after treatment with NOS blockers. These findings raised the question of whether inhibitors of iNOS could be used in vivo to prevent the development of type 1 diabetes. However, a high selectivity for iNOS seems important to prevent side effects that might arise from inhibiting the other isoforms. Also, a drug with a high selectivity for iNOS can inhibit enzyme molecules from cells not implicated in beta cell damage.

Diabetes transfer from mouse to mouse constitutes an experimental model in which insulin secretion impairment was induced in healthy naïve recipient mice by MS from mld-SZ diabetic donors and it appears to be a useful system to study mechanisms involved in the onset and modulation of autoimmune pancreatic aggression (Enghofer et al., 1998; Karabatas et al., 2000 and 2005 and Pastorale et al., 2002).

Paik et al., (1980) showed that splenocytes from mld-SZ +/nu mice induced transient glucose intolerance in $\mathrm{nu} / \mathrm{nu}$ recipients and this effect was eliminated when splenocytes were depleted of T cells. In addition, Arata et al., (1994) showed that diab.MS induced abnormal glucose tolerance and impaired insulin secretion in healthy syngeneic recipients; when diab.MS were labeled with $\mathrm{Na}_{2}{ }^{51} \mathrm{CrO}_{4}$, they showed a specific homing towards the pancreas of recipient mice indicating an early event in the immune aggression. Also, peripheral blood mononuclear cells from newly diagnosed type 1 diabetic patients migrate to the pancreas of athymic mice showing again a specific trapping (Arata et al., 1995). Moreover, Enghofer et al., (1998) showed that transfer of lymphocytes from spleens of mld-SZ mice, stained with acridine red, resulted in increased lymphocyte rolling and endothelial adhesion only in islets of recipient mice pretreated with a single subdiabetogenic dose of streptozotocin. It has been suggested that the pool of transferred splenic lymphocytes from mld-SZ mice contain immunologically-activated isletspecific cells that trigger the immune aggression in this diabetic model.
Here and in previous studies (2005) we show that diab.MS obtained at day 4 were able to impair glucose-induced insulin secretion when transferred to syngeneic animals. In addition we have reported (2000) that mice transferred three times with diab.MS showed hyperglycemia and diminished first peaks of glucose and arginine-induced insulin secretion. These findings indicate that the capacity of diab.MS to impair beta-cell function can be modulated.

When diab.MS, obtained at days 6 and 16, were pre-cultured with $0.5 \mathrm{mM}$ L-NMMA, $\mathrm{NO}^{\circ}$ production diminish to control values. Is not clear why L-NMMA is unable to suppress $\mathrm{NO}^{\circ}$ production from ctr.MS. We can speculate that the concentration of LNMMA used in the culture was not high enough to completely inhibit $\mathrm{NO}^{\circ}$ synthesis.

When we pre-cultured diab.MS with LNMMA and then transferred them to syngeneic mice, we found different patterns of response: when MS were obtained at day 4 they lost the capacity to impair glucose-induced insulin secretion in recipient mice; when diab.MS were obtained at days 6 and 9 this impairment was partial and, at day 16 completely manifested. We have not tested if L-NMMAtreated diab.MS lose the inhibition in $\mathrm{NO}^{\circ}$ production if cultured again without LNMMA. However, we think that the inhibition persist since mice transferred with diab.MS (pre-cultured with L-NMMA) and killed 15 days later showed a reduced impairment in insulin secretion.

The capacity of diab.MS to reduce stimulated insulin secretion can also be studied by means of co-culturing them with dispersed rat or mouse islet cells (in vitro model) as an evaluation of the cellular immune aggression (CIA). One of the features of the CIA test is the absence of conventional major histocompatibility complex restriction, since previous studies have shown that peripheral blood mononuclear cells from newly diagnosed type 1 diabetic patients were able to induce CIA in rat and murine pancreatic beta cells. Also, MS from mld-SZ mice were found to produce CIA on dispersed rat islet cells 
(Boitard et al., 1982; Arata et al., 1995; Karabatas et al., 1996). In this study, we used rat islets because they are more easily isolated and hand-picked than mouse islets.

CIA seems to be specific for pancreatic beta cells, because no cytotoxicity is observed against fibroblasts, and secretion of glucagon and somatostatin remains unaffected (Boitard et al., 1982; Arata et al., 1994). In this study, diab.MS present CIA at an early stage (such as day 4 after mld-SZ) concomitantly with their increment in $\mathrm{NO}^{\circ}$ production. These facts occur before hyperglycemia and reduced insulin secretion appear in donor mice.

Diab.MS pre-cultured with L-NMMA also exerted a reduced CIA since dispersed islet cells secreted higher levels of insulin secretion. However, the preventive effect of L-NMMA on CIA is not observed at day 16. It is possible that at later stages diab. MS affect beta cells by means of other inflammatory agents in addition to free radicals (Cernea et al., 2008; Lehuen et al., 2010; Buschard K, 2011).

\section{Conclusions}

The in vitro inhibition of $\mathrm{NO}^{\circ}$ production causes a reduction in the capacity of diab.MS to impair insulin secretion in beta cells. This effect occurs both when MS are co-cultured with dispersed islet cells (CIA) or transferred to syngeneic recipient mice. However, L-NMMA is not effective when MS are isolated from donor mice at later stages of the development of diabetes.

These results suggest that modification of the aggressive capacity of diab.MS, avoid, at least in part, beta cell damage and destruction.

\section{Acknowledgements}

This study was supported with Grants PICT 05-06960/BID 1201 OC/AR and PICT 0538157 BID 1728 0.C/AR from the Agencia Nacional de Promoción Científica y Tecnológica.

We greatfully thank Dr. Yolanda B. Lombardo and Dr. Adriana Chicco (Facultad de Bioquímica y Ciencias Biológicas, Universidad Nacional del Litoral, Santa Fe, Argentina) and Dr. Sabina
Domene and Dr. Rodolfo Rey (CEDIE, Buenos Aires, Argentina) for their helpful advice and comments on the manuscipt. The experts technical assistance of Mr. Eduardo Dascal is greatly acknowledge.

We specially wish to express our gratitude to Dr. Juan Carlos Basabe. For many years he was the chief of our laboratory and he honored us with his advice, his knowledge and his friendship. He contributed to the initial steps of this research. Unfortunately he died in 2010 .

\section{Declaration of Interest}

No potential conflicts of interest relevant to this article were reported.

\section{References}

1. Arata, M, Fabiano de Bruno, L, Goncalvez Volpini, W. M, Quintans, J. C, DÁlessandro, V. G, Braun, M and Basabe, J.C. (1994) "Beta cell function in mice injected with mononuclear splenocytes from multipledose streptozotocin diabetic mice." Proceedings of the Society for Experimental Biology and Medicine, 206(1): 76-82.

2. Arata, M, Fabiano de Bruno, L, Goncalvez Volpini, W, Gagliardi, G, Quintans, J. C and Basabe, J.C. (1995) "Insulin secretion by pancreas of athymic mice injected with peripheral mononuclear cells from insulindependent diabetic patients". Metabolism 44(11):1435-1441.

3. Boitard, C, Chatenoud, L and Debray-Sach N.(1982) “ In vitro inhibition of pancreatic beta cell function by lymphocytes from diabetics with associated autoimmune diseases: a T cell phenomenon." Journal of Immunol, 129(6):2529-2531.

4. Buschard, K and Rygaard, J. (1977) "Passive transfer of streptozotocin induced diabetes mellitus with spleen cells." Acta Pathologica et Microbiologica Scandinavica, 85C(6): 469-472.

5. Buschard, K.. (2011) "What causes type 1 diabetes? Lessons from animal models." Acta Pathologica, Microbiologica et Immunologica Scandinavica, 119 (Suppl 132): 1-19. 
6. Cernea, S and Pozzilli, P. (2008) "New potential treatments for protection of pancreatic B-cell function in Type 1 diabetes." Diabetic Medicine, 25(11): 12591267.

7. Eizirik, D. L, Colli, M. L and Ortis, F. (2009). "The role of inflammation in insulitis and beta-cell loss in type 1 diabetes." Nature Reviews Endocrinology, 5(4): 219-226.

8. Enghofer, M, Bojunga, J, Ludwig, R, Oldenburg,A,Bernd, A,Usadel, K.H and Kusterer K. (1998) "Lymphocyte transfer in streptozotocin-induced diabetes: adhesion of donor cells to islet endothelium." American Journal of Physiology, 274(5 Pt 1):E928-E935.

9. Flodstrom, M, Tyrberg, B, Eizirik, D. L and Sandler S. (1999) "Reduced sensitivity of inducible nitric oxide synthase-deficient mice to multiple low-dose streptozotocininduced diabetes." Diabetes, 48(4): 706713.

10. Green, L. C, Wagner, D. A, Glogowsky, J, Skipper, P. L, Wishnok J. S and Tannenbaum S. R. (1982) "Analysis of nitrate, nitrite, and $\left[{ }^{15} \mathrm{~N}\right]$ nitrate in biological fluids." Analytical Biochemistry, 126(1): 131- 138.

11. Herbert, V, Lau, K, Gottlieb, C. H and Bleicher, S. J. "Coated charcoal immunoassay of insulin." Journal of Clinical Endocrinology and Metabolism, 1965; 25: 1375- 1384.

12. Herold, K. C, Montag, A. G and Fitch, F. W. (1987). "Treatment with anti-Tlymphocyte antibodies prevents induction of insulitis in mice given multiple doses of streptozotocin." Diabetes, 36(7), 796-801.

13. Karabatas, L, Pastorale, C, de Bruno L. F, Maschi, F, Pivetta, O. H, Lombardo, Y. B, Chemes, H and Basabe, J. C. (2005) "Early manifestations in multiple-low-dose streptozotocin-induced diabetes in mice." Pancreas, 30(4): 318-324.

14. Karabatas, L. M, De Bruno, L. F, Pastorale, C, Lombardo, Y. B and Basabe, J. C. (2000) "Branched-chain amino acids enriched diet: effects on insulin secretion and on cellular immune aggression." Proceedings of the Society for Experimental Biology and Medicine, 224(3): 159-165.

15. Karabatas, L. M, Fabiano de Bruno, L, Pastorale, C. F, Cullen, C and Basabe, J. C. (1996) "Inhibition of nitric oxide generation: normalization of in vitro insulin secretion in mice with multiple lowdose streptozotocin and in mice injected with mononuclear splenocytes from diabetic syngeneic donors." Metabolism, 45(8): 940-946.

16. Karatug, A and Bolkent, S. (2013) "The potential role of combined antioxidant treatment on pancreas of STZ-diabetic mice" Experimental and Toxicologic Pathology, 65(3): 255-262.

17. Lacy, P. E and Kostianovsky, M. (1967) Method for the isolation of intact islets of Langerhans from the rat pancreas." Diabetes, 16(1):35-39.

18. Lehuen, A, Diana, J, Zaccone, $P$ and Cooke, A. (2010). "Immune crosstalk in type 1 diabetes." Nature Reviews Immunology, 10(7): 501-513.

19. Lenzen, S. (2008) "Oxidative stress: the vulnerable ß-cell." Biochemical Society Transactions, 36(Pt3): 343-347.

20. Like, A. A and Rossini A. A. (1976) "Streptozotocin-induced pancreatic insulitis: new model of diabetes mellitus." Science, 193(4251): 415-417.

21. Mabley, J. G, Pacher, P, Murthy, K. G. K, Williams, W, Southan, G. J, Salzman, A. L and Szabo, C. (2008) "The novel inosine analogue, INO-2002, protects against diabetes development in multiple low-dose streptozotocin and non-obese diabetic mouse models of type I diabetes." Journal of Endocrinology, 198(3):581-589

22. Mabley, J. G, Southan, G. J, Salzman, A. L, Szabo, C. (2004) "The combined inducible nitric oxide synthase inhibitor and free radical scavenger guanidinoethyldisulfide prevents multiple low-dose streptozotocininduced diabetes in vivo and interleukin1 beta-induced suppression of islet insulin secretion in vitro." Pancreas, 28(2): E39-44. 
23. Maksimovic-Ivanic, D, Trajkovic, V, Miljkovic D. J, Mostarica Stojkovic, M and Stosic-Grujicic S. (2002) "Down-regulation of multiple low dose streptozotocininduced diabetes by mycophenolate mofetil." Clinical and Experimental Immunology, 129(2): 214-223.

24. Nakamura, M, Nagafuchi, S, Yamaguchi, K and Takaki, R. (1984). "The role of thymic immunity and insulitis in the development of streptozocin-induced diabetes in mice." Diabetes, 33(9), 894-900.

25. O’Brien, B. A, Harmon, B. V, Cameron, D. $\mathrm{P}$ and Allan, D. (1996) "Beta-cell apoptosis is responsible for the development of IDDM in the multiple low-dose streptozotocin model." The Journal of Pathology, 178(2):176-181.

26. Ono, J, Takaki, R and Fukuma, M. (1977) "Preparation of single cells from pancreatic islets of adult rats by the use of dispase" Endocrinologia Japonica, 24(3):265-270.

27. Padgett, L. E, Broniowska, K. A, Hansen, P. A, Corbett, J. A and Tse, H. M. (2013). "The role of reactive oxygen species and proinflammatory cytokines in type 1 diabetes pathogenesis." Annals of the New York Academy of Sciences, 1281, 16-35.

28. Paik, S. G, Fleischer, N and Shin S. I. (1980). "Insulin-dependent diabetes mellitus induced by subdiabetogenic doses of streptozotocin: obligatory role of cellmediated autoinmune processes." Proceedings of the National Academy of Sciences, 77(10), 6129-6133.

29. Pastorale, C, Arata, M, Caminos, A, Bruno, L, Basabe, J. C, and Chemes, H. (2002) "Effect of modified diabetic splenocytes on mice injected with multiple low-dose streptozotocin." Experimental Biology and Medicine, 227(4): 282-289.

30. Per-Ola, C, Flodstrom, M and Sandler S. (2000) "Islet blood flow in multiple low dose streptozotocin treated wild-type and inducible nitric oxide synthase-deficient mice." Endocrinology, 141(8): 2752-2757.

31. Phillips, H. J. (1973) "Dye exclusion test for cell viability", in Kruse G, Patterson C (ed): Tissue: methods and applications. New York, Academic Press, pp 406-408.

32. Pighin, D, Karabatas, L, Pastorale, C, Dascal, E, Carbone, C, Chicco, A, Lombardo, Y. B and Basabe JC. (2005) "Role of lipids in the early developmental stages of experimental immune diabetes induced by multiple low-dose streptozotocin." Journal of Applied Physiology, 98(3): 1064-1069.

33. Rydgren, T and Sandler, S. (2002) "Efficacy of $1400 \mathrm{~W}$, a novel inhibitor of inducible nitric oxide synthase, in preventing interleukin-1 $\beta$-induced suppression of pancreatic islet function in vitro and multiple low-dose streptozotocininduced diabetes in vivo." European Journal of Endocrinology, 147(4): 543-551.

34. Stosic-Grujicic, S. D, Maksimovic, D, Badovinac, V, Samardzić, T, Trajković, V, Lukić, $\mathrm{M}$ and Mostarica Stojković, M. (2001) "Antidiabetic effect of pentoxifylline is associated with systemic and target tissue modulation of cytokines and nitric oxide production". Journal of Autoimmunity, 16(1):47-58.

35. Wang, Z and Gleichmann, H. (1998) "GLUT2 in pancreatic islets. Crucial target molecule in diabetes induced with multiple low doses of streptozotocin in mice." Diabetes, 47(1): 50-56.

36. Yang, Z, Chen, M, Fialkow, L. B, Ellett, J. $\mathrm{D}, \mathrm{Wu}, \mathrm{R}$ and Nadler, J. L. (2003) "The novel anti-inflammatory compound, lisofylline, prevents diabetes in multiple low-dose streptozotocin-treated mice." Pancreas, 26(4): E99-E104.

37. Yaochite, J. N, Caliari-Oliveira, C, Davanso, M. R, Carlos, D, Malmegrim, K. C, Cardoso, C. R, Ramalho, L. N, Palma, P. V, da Silva, J. S, Cunha, F. Q, Covas, D. T and Voltarelli, J. C. (2013). "Dymanic changes of the Th17/Tc17 and regulatory $\mathrm{T}$ cell populations interfere in the experimental autoinmune diabetes pathogenesis." Immunobiology, 218(3), 338-352.

38. Yasuda, H, Jin, Z, Nakayama, M, Yamada, K, Kishi, M, Okumachi, Y, Arai, T, Moriyama, 38. H, Yokono, K and Nagata, M. (2009). "NO-mediated cytotoxicity contribuyes to 
multiple low-dose streptozotocin-induced diabetes but not to NOD diabetes." Diabetes Research and Clinical Practice, 83(2): 200-207. 